NASA/TM-2001-211135

High Voltage SPT Performance

David Manzella

University of Toledo, Toledo, Ohio

David Jacobson and Robert Jankovsky

Glenn Research Center, Cleveland, Ohio 
Since its founding, NASA has been dedicated to the advancement of aeronautics and space science. The NASA Scientific and Technical Information (STI) Program Office plays a key part in helping NASA maintain this important role.

The NASA STI Program Office is operated by Langley Research Center, the Lead Center for NASA's scientific and technical information. The NASA STI Program Office provides access to the NASA STI Database, the largest collection of aeronautical and space science STI in the world. The Program Office is also NASA's institutional mechanism for disseminating the results of its research and development activities. These results are published by NASA in the NASA STI Report Series, which includes the following report types:

- $\quad$ TECHNICAL PUBLICATION. Reports of completed research or a major significant phase of research that present the results of NASA programs and include extensive data or theoretical analysis. Includes compilations of significant scientific and technical data and information deemed to be of continuing reference value. NASA's counterpart of peerreviewed formal professional papers but has less stringent limitations on manuscript length and extent of graphic presentations.

- TECHNICAL MEMORANDUM. Scientific and technical findings that are preliminary or of specialized interest, e.g., quick release reports, working papers, and bibliographies that contain minimal annotation. Does not contain extensive analysis.

- CONTRACTOR REPORT. Scientific and technical findings by NASA-sponsored contractors and grantees.
- CONFERENCE PUBLICATION. Collected papers from scientific and technical conferences, symposia, seminars, or other meetings sponsored or cosponsored by NASA.

- SPECIAL PUBLICATION. Scientific, technical, or historical information from NASA programs, projects, and missions, often concerned with subjects having substantial public interest.

- TECHNICAL TRANSLATION. Englishlanguage translations of foreign scientific and technical material pertinent to NASA's mission.

Specialized services that complement the STI Program Office's diverse offerings include creating custom thesauri, building customized data bases, organizing and publishing research results ... even providing videos.

For more information about the NASA STI Program Office, see the following:

- Access the NASA STI Program Home Page at http://www.sti.nasa.gov

- E-mail your question via the Internet to help@sti.nasa.gov

- Fax your question to the NASA Access Help Desk at 301-621-0134

- Telephone the NASA Access Help Desk at 301-621-0390

- Write to:

NASA Access Help Desk

NASA Center for AeroSpace Information 7121 Standard Drive

Hanover, MD 21076 
NASA/TM-2001-211135

AIAA-2001-3774

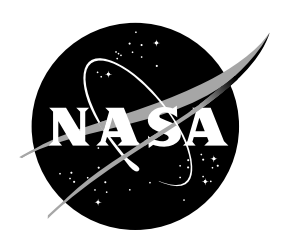

\section{High Voltage SPT Performance}

David Manzella

University of Toledo, Toledo, Ohio

David Jacobson and Robert Jankovsky

Glenn Research Center, Cleveland, Ohio

Prepared for the

37th Joint Propulsion Conference and Exhibit

cosponsored by the AIAA, SAE, AIChE, and ASME

Salt Lake City, Utah, July 8-11, 2001

National Aeronautics and

Space Administration

Glenn Research Center 
Available from

NASA Center for Aerospace Information 7121 Standard Drive

Hanover, MD 21076
National Technical Information Service 5285 Port Royal Road Springfield, VA 22100

Available electronically at http:/ /gltrs.grc.nasa.gov/GLTRS 


\title{
HIGH VOLTAGE SPT PERFORMANCE
}

\author{
David Manzella \\ University of Toledo \\ Toledo, Ohio 43606 \\ David Jacobson and Robert Jankovsky \\ National Aeronautics and Space Administration \\ Glenn Research Center \\ Cleveland, Ohio 44135
}

\section{SUMMARY}

A $2.3 \mathrm{~kW}$ stationary plasma thruster designed to operate at high voltage was tested at discharge voltages between 300 and $1250 \mathrm{~V}$. Discharge specific impulses between 1600 and $3700 \mathrm{sec}$ were demonstrated with thrust between 40 and $145 \mathrm{mN}$. Test data indicated that discharge voltage can be optimized for maximum discharge efficiency. The optimum discharge voltage was between 500 and $700 \mathrm{~V}$ for the various anode mass flow rates considered. The effect of operating voltage on optimal magnet field strength was investigated. The effect of cathode flow rate on thruster efficiency was considered for an $800 \mathrm{~V}$ discharge.

\section{INTRODUCTION}

Over the last several decades research and development of Hall thruster propulsion has focused on a number of technical objectives. These include: the qualification of Hall thruster systems for on-orbit station keeping with powers ranging from near $1 \mathrm{~kW}$ up to $5 \mathrm{~kW}$ (refs. 1 to 3), the development of Hall thrusters and systems that operate efficiently at the specific impulses suitable for station-keeping and can also provide a high thrust-to-power ratio for orbit insertion of low Earth orbit (LEO) and geosynchronous orbit (GEO) spacecraft (refs. 4 and 5), the investigation of low power Hall thrusters for use on small, power limited spacecraft (ref. 6), and investigations into high power Hall thrusters for a new class of missions including LEO to GEO space transportation, human exploration and development of space (HEDS) (refs. 7 and 8), and space solar power. This investigation considers Hall thrusters capable of operation at specific impulses above the current state-of-the-art (1500 to $1800 \mathrm{sec}$ ), but less than that provided by state-of-the-art gridded ion thruster systems (3000 sec and above).

The motivation for this investigation is that propulsion systems utilizing Hall thrusters with specific impulses between 1800 and $3000 \mathrm{sec}$ may offer substantial spacecraft mission benefits (ref. 9). These may include either a reduction in spacecraft wet mass (often times permitting a reduction in launch vehicle class) or an increase in spacecraft lifetime (at the expense of longer trip time or firing duration for power limited applications). However, measurements of the operational characteristics of Hall thrusters operating in this range of specific impulse are required to more accurately estimate these potential benefits.

To that end, NASA Glenn Research Center (GRC) solicited proposals for thrusters with performance characteristics approaching those of the state-of-art NSTAR gridded ion thruster. The specific goal was to obtain $2.3 \mathrm{~kW}$ laboratory model thrusters that could operate using xenon as the propellant at $3200 \mathrm{sec}$ while providing $100 \mathrm{mN}$ of thrust. Two suppliers were selected to build such thrusters. The first supplier was the Boeing Corporation that proposed a two stage anode layer thruster (TAL). Jacobson, et al., (ref. 10) provides details regarding the characteristics of this thruster in a companion paper. The second supplier selected was Atlantic Research Corporation (ARC). The thruster they supplied, which was fabricated through subcontract to the Fakel Design Bureau in Russia, is a stationary plasma thruster (SPT) of hybrid design. This design utilized a conventional dielectric material for the discharge chamber near the thruster exit plane and used metal construction as in TAL thrusters for the rear of the discharge chamber. The following report will summarize the important characteristics of this thruster, indicate the test apparatus used for and experimental evaluation of the thruster at GRC, and discuss the significance of these results.

\section{APPARATUS AND PROCEDURE}

The hybrid SPT thruster provided by ARC is a design derived from the flight model SPT-100 thruster. A photograph of this thruster, called the SPT-1, is shown in figure 1. The nominal outside diameter of the discharge chamber was $100 \mathrm{~mm}$. While it was possible to independently supply propellant at the rear or either side of the annular anode, all testing was conducted with 100 percent of the xenon anode flow injected at the rear. The thruster 


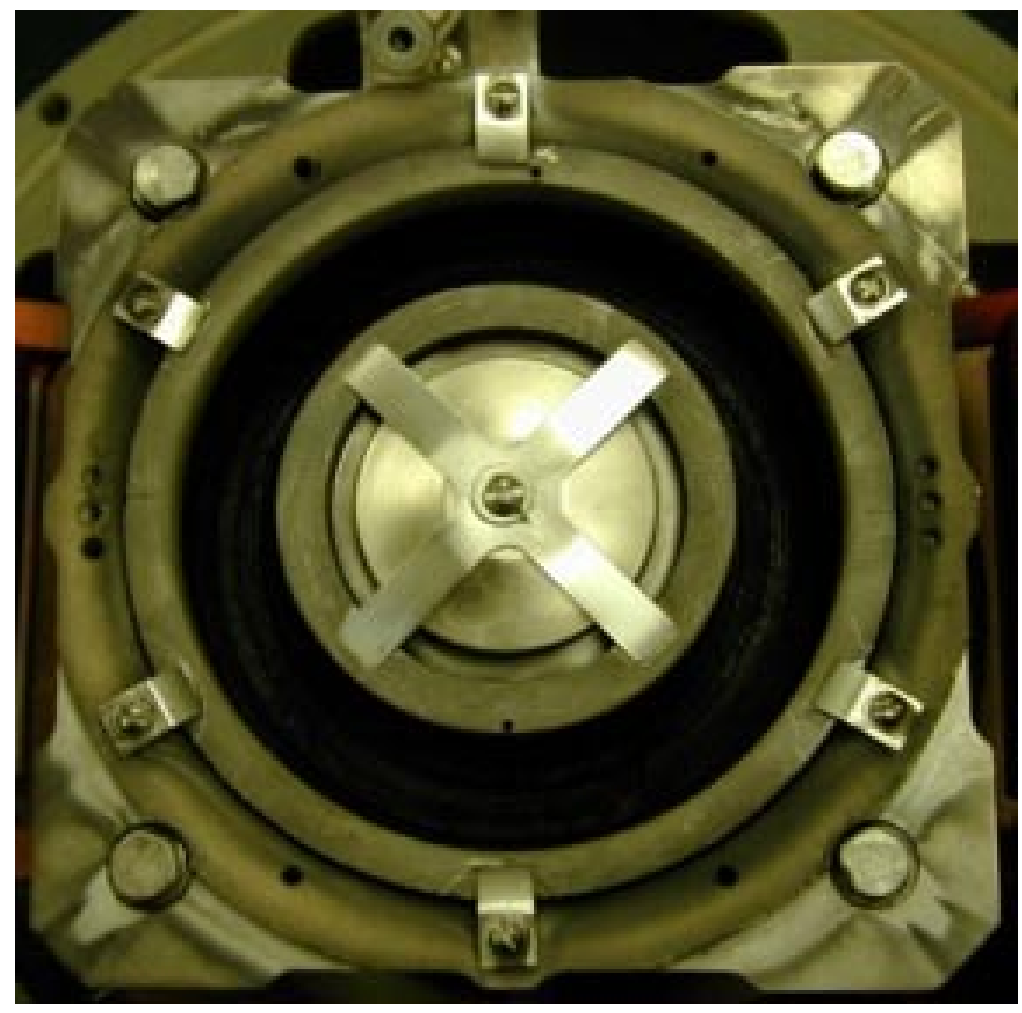

Figure 1.-SPT-1 high voltage stationary plasma thruster.

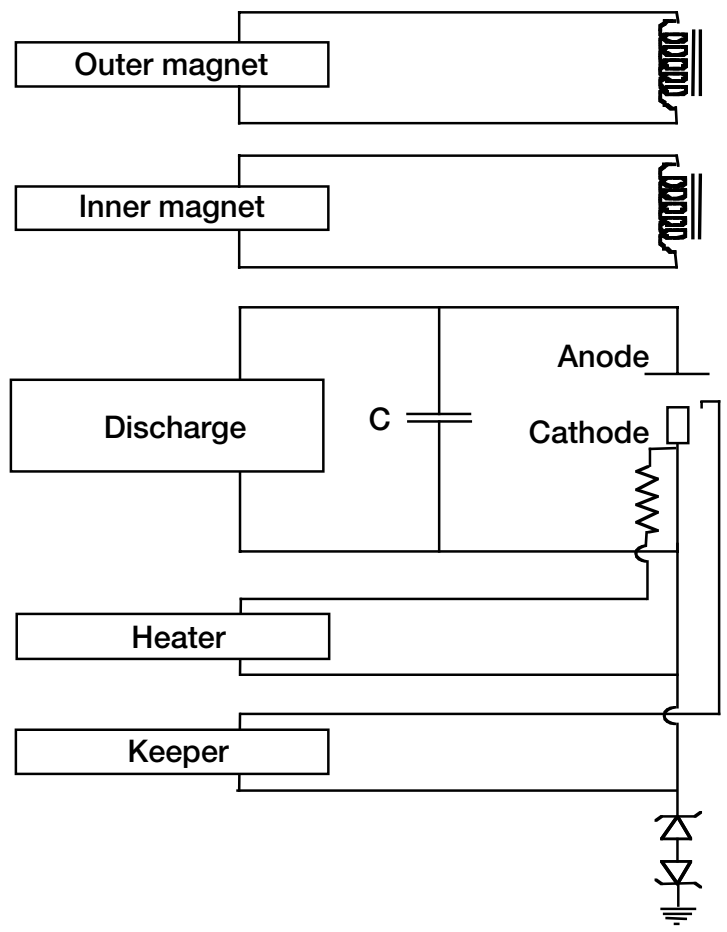

Figure 2.-Electrical schematic of test configuration. 
was operated at total input powers between 1.0 and $3.2 \mathrm{~kW}$. This was accomplished by providing anode xenon flow rates ranging from 2.4 to $5.4 \mathrm{mg} / \mathrm{sec}$ at discharge voltages between 300 and $1250 \mathrm{~V}$. A laboratory model cathode was used for all testing. Neither cathode position nor cathode flow rate was optimized for operation with this engine. The cathode shown on the thruster at the top of the photograph in figure 1 is a cold start cathode that was not used during testing.

The thrust produced by the SPT-1 was measured using an inverted pendulum design thrust stand which has been used in previous evaluations of Hall effect thrusters (refs. 11 to 12). Data were taken in a large cryogenically pumped vacuum chamber at NASA GRC. The cylindrical vacuum chamber was $20 \mathrm{~m}$ long and $8 \mathrm{~m}$ in diameter. During testing the maximum background pressure was $3 \times 10^{-6}$ torr at a total xenon flow of $5.8 \mathrm{mg} / \mathrm{sec}$. This corresponded to a xenon pumping speed of approximately $250,000 \mathrm{~L} / \mathrm{sec}$.

A schematic of the electrical configuration used is shown in figure 2. Commercially available power supplies were used to run the discharge, cathode heater, magnets, and cathode ignitor/keeper. A nonoptimized output filter consisting of a $100 \mu \mathrm{F}$ capacitor was used between the thruster and the discharge power supply. Independent control of the inner and outer magnet supplies was utilized. This permitted optimization of the magnetic field at each operating point. This was done by systematically adjusting the current to each so as to minimize the discharge current. The effect of this magnet optimization is shown graphically in figure 3. In this case the thruster optimized at approximately 4.5 A of outer magnet current and 7.5 A of inner magnet current. The entire electrical system was allowed to float relative to ground. At no time was the cathode more than $20 \mathrm{~V}$ negative with respect to facility ground. This was maintained by using back-to-back $20 \mathrm{~V}$ Zener diodes.

The thruster and cathode were operated on commercially available research grade xenon (purity better than 99.9995 percent). A feed system with commercially available mass flow controllers was used to provide the desired flow rates. The flow controllers were calibrated both before and after testing using a constant volume technique. Uncertainties in mass flow rate measurements were estimated to be \pm 2 percent. The thrust stand was calibrated in-situ using three weights with a mass of approximately $0.010 \mathrm{~kg}$ each. The uncertainty in the thrust measurements, primarily due to zero drift, was estimated to be \pm 1.5 percent. Thrust measurements were taken after operation of the thruster for approximately $1 \mathrm{hr}$ to allow for thruster to approach steady state operating temperatures. At each operating point the inner and outer magnet currents were adjusted to minimize the discharge current at a constant anode flow and discharge voltage. This technique of determining optimal performance by minimizing discharge current has been previously discussed (ref. 13).

\section{RESULTS AND DISCUSSION}

The thruster was operated at seven different anode flow rates and voltages ranging from 300 to $1250 \mathrm{~V}$. The maximum voltage tested for a given flow rate corresponded to $3200 \mathrm{~W}$. Operation at powers above $3200 \mathrm{~W}$ was not investigated due to thermal limitations of the thruster. The voltage current characteristics from these test data are shown in figure 4. At each point the magnets were adjusted in an attempt to minimize the discharge current. For each anode flow rate the discharge current increases slightly with voltage in a near linear fashion starting at $300 \mathrm{~V}$. At an intermediate voltage, e.g., $750 \mathrm{~V}$ for the $2.4 \mathrm{mg} / \mathrm{sec}$ anode flow rate case, the discharge current begins to increase at a greater rate with increasing voltage. The increase in discharge current with increasing discharge voltage is near linear above this intermediate voltage as well. The absolute value of the intermediate voltage, where the discharge current versus discharge voltage relationship changed, decreased with increasing anode mass flow rate. The increase in discharge current with increasing discharge voltage for a given anode mass flow rate can be attributable to either an increase in ion current or electron current. It is thought that for $300 \mathrm{~V}$ operation the anode propellant is very nearly all singly ionized. Therefore, if the increase in anode current is due to increased ion current, significant number of multiply charged ions must be present. It is also possible that the increase in discharge current at higher voltages was due to electron current. If the increase is due to additional electron current, there must be enhanced axial electron transport across the radial magnetic field region at higher voltages. Additional measurements will need to be made to answer this question definitively.

Figure 5 shows the functional relationship between discharge specific impulse (specific impulse determined based on the anode flow only) and thrust for each of the anode flow rates investigated. For those flow rates that were operated at voltages above $1000 \mathrm{~V}(2.4$ and $2.9 \mathrm{mg} / \mathrm{s})$ a greater than $2: 1$ spread in both specific impulse and thrust was demonstrated. The lack of high specific impulse points for the higher flow rates was again due to thruster thermal limitations. The rate of increase in discharge specific impulse with thrust is nearly linear in each case, however, as the mass flow rate increases the rate at which the specific impulse increases with thrust is less. This was attributed to an overall increase in discharge efficiency at higher mass flow rates which will be shown in a subsequent figure.

Figure 6 shows the discharge specific impulse plotted versus the discharge voltage. The curve fit is based on the square root of the discharge voltage assuming a simple relationship between the applied voltage and the average exhaust velocity. The curve fit was a best fit to all the data independent of flow rate. The trend at the lower mass flow rates exhibited a slightly lower discharge specific impulse for a given discharge voltage was again attributed to 


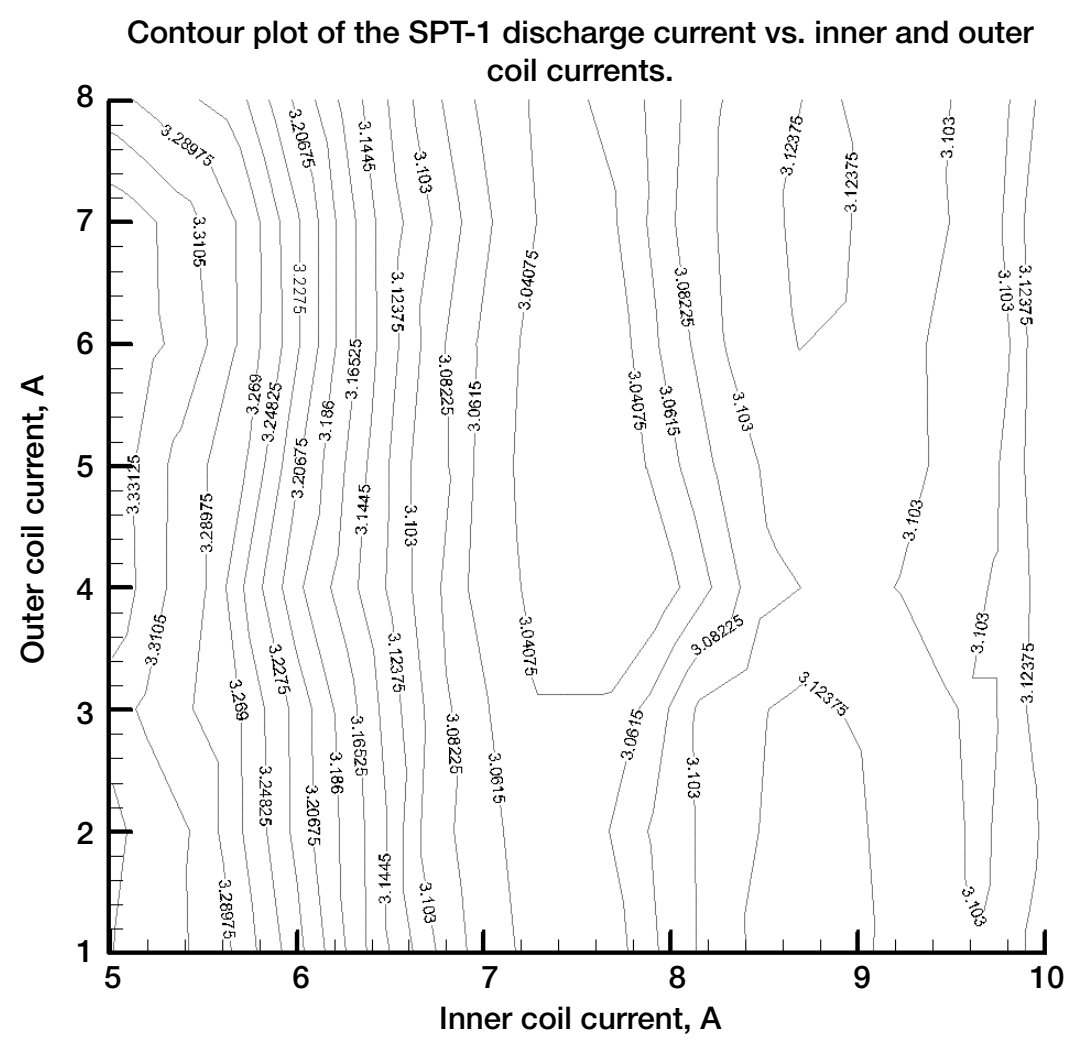

Figure 3.-Effect of magnet current on discharge current.

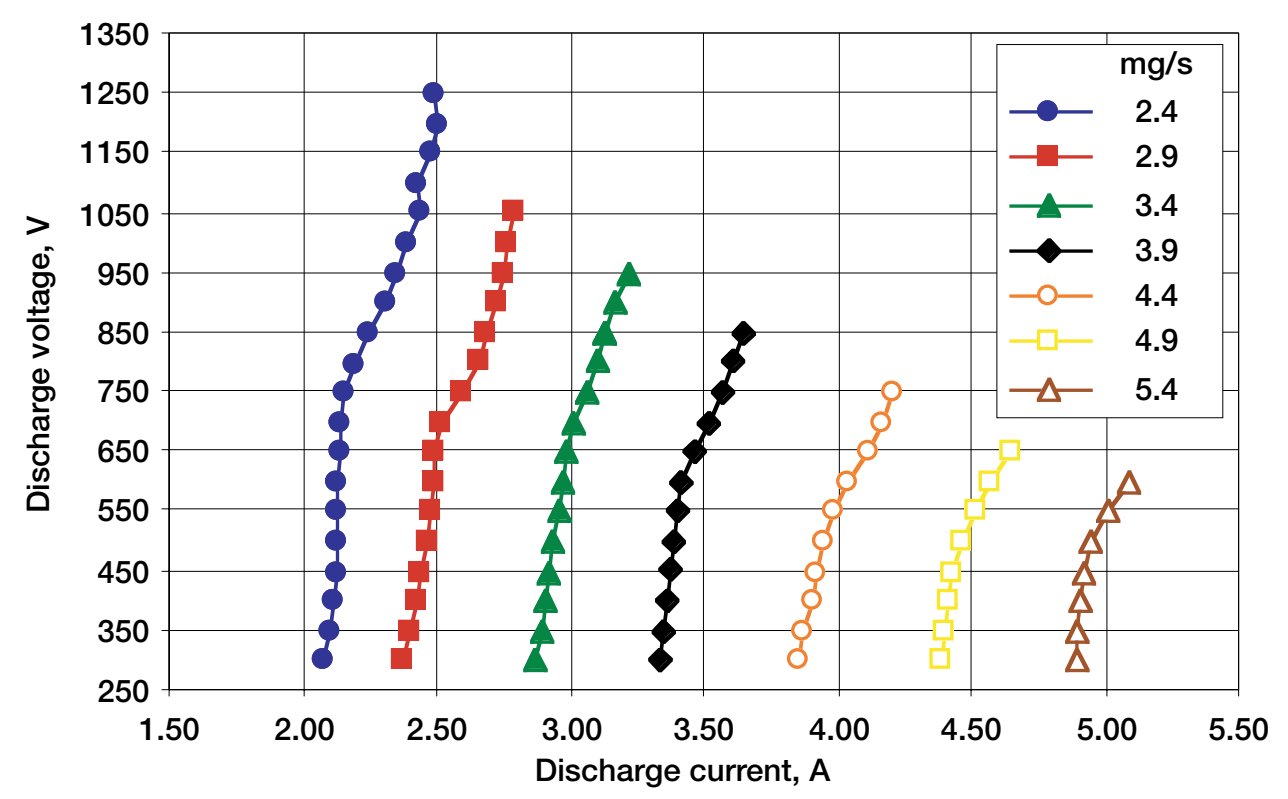

Figure 4.-Voltage/current characteristic. 


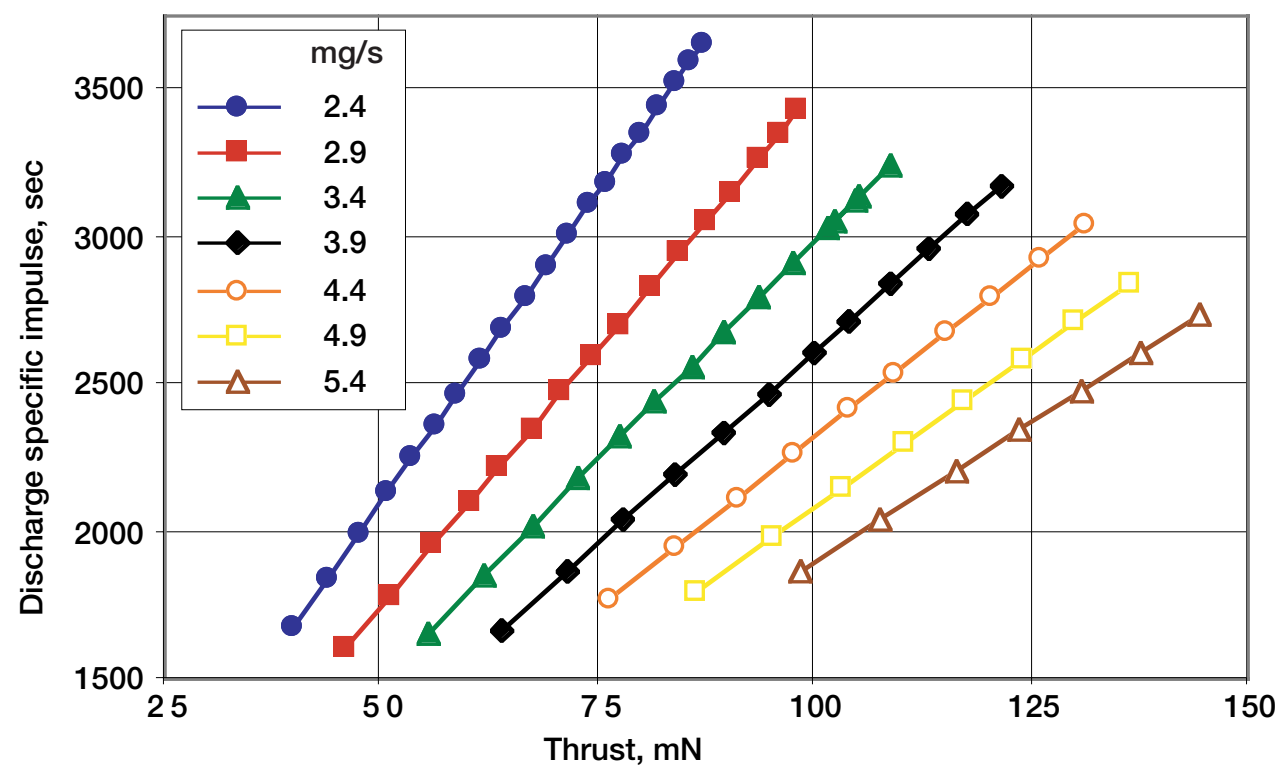

Figure 5.-Discharge specific impulse versus thrust.

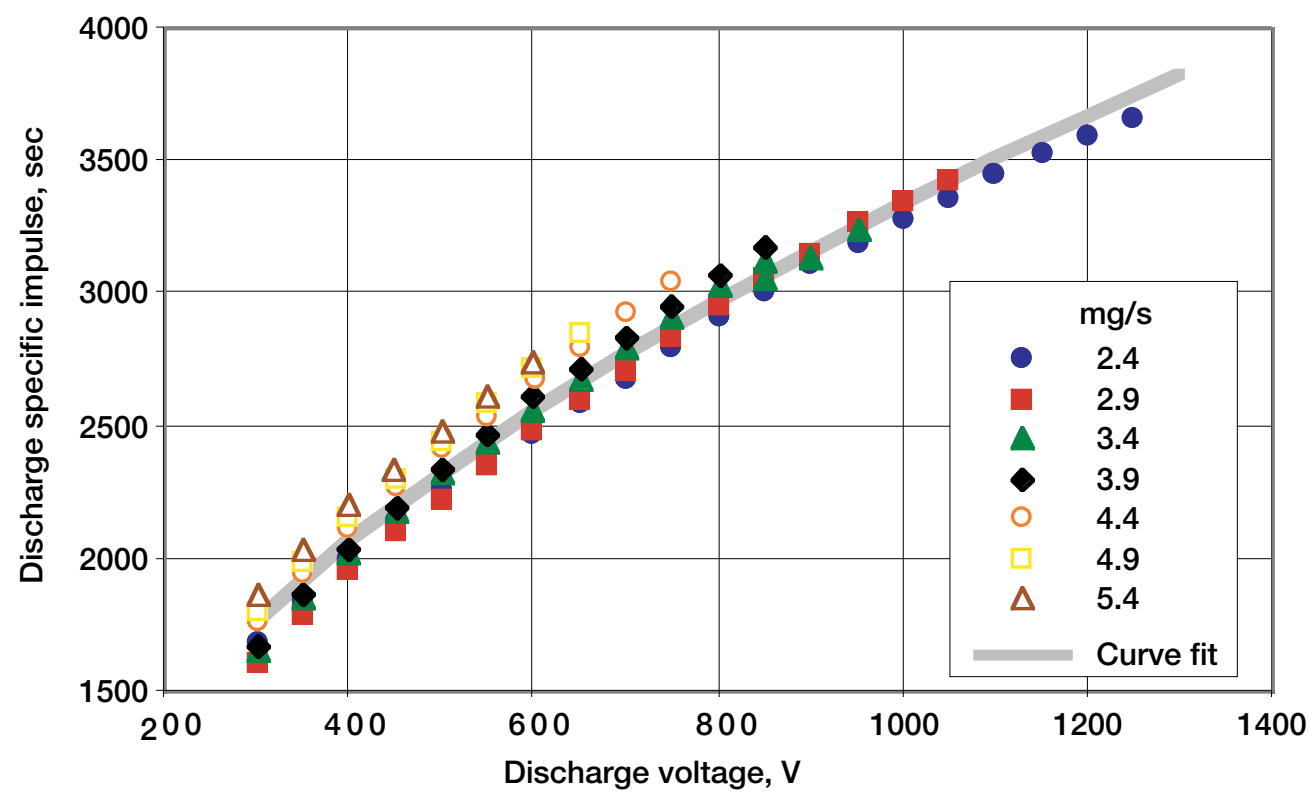

Figure 6.-Discharge specific impulse versus discharge voltage. 
an overall increase in discharge efficiency at higher mass flow rates. This also shows that the initial design goal for this engine of $3200 \mathrm{sec}$ of specific impulse was obtained at a discharge voltage near $1000 \mathrm{~V}$.

The suitability of operating the SPT-1 thruster at this high of a voltage is shown in figure 7 where discharge efficiency (efficiency determined based on the anode flow only and discharge power only) is plotted versus discharge voltage. As previously intimated, it can be seen that there was a significant increase in discharge efficiency with increasing anode mass flow rate. It can also be seen that the maximum discharge efficiency for a given anode flow rate occurred at some intermediate discharge voltage. Furthermore, the value of the discharge voltage corresponding to maximum discharge efficiency approximately corresponds to the intermediate voltage mentioned during the discussion of the voltage current characteristics shown in figure 4 . Above the optimal discharge voltage the decrease in discharge efficiency is accompanied by an increase in the relative rate of change of discharge current with discharge voltage. This seems to suggest an increase in electron current at elevated voltages rather than multiply charged ions. It is also likely that this relationship between efficiency, voltage, and mass flow rates occurs at channel densities that best optimize the processes of ionization and acceleration with respect to the various thruster loss mechanisms. These data, and similar data obtained by Jacobson et al., (ref. 10) generated using an anode layer thruster do suggest, however, that while ion-thruster-like specific impulses are obtainable with Hall thrusters, efficient operation is obtained at discharge voltages in the 500 to $800 \mathrm{~V}$ range which correspond to 2000 to $3000 \mathrm{sec}$ of specific impulse. Based on the variability of the peak efficiency with flow rate and discharge voltage it is clear that a more thorough understanding of these phenomena are needed for optimal design of high voltage stationary plasma thrusters.

To that end the effect of varying the discharge voltage on the optimal magnet settings was considered. In figure 8 the sum of the inner and outer magnet currents are plotted versus discharge voltage. While the sum of the magnet currents is not a precise indicator of the magnetic field strength it is a good indicator of what the radial magnetic field strength is within the channel. It has been suggested that the peak magnetic field strength should scale as the square root of the discharge voltage (ref. 14). In general, these data support this supposition based on the $\mathrm{V}^{0.5}$ curve fits shown in the figure. Interestingly, for anode flow rates up to $3.9 \mathrm{mg} / \mathrm{s}$, the curves seem to share the same functional dependency with their slope increasing with anode flow. At anode flow rates of $4.4 \mathrm{mg} / \mathrm{s}$ and higher the slope no longer increases with increasing anode flow rate. No clear explanation for this behavior was suggested by the data and it should be reiterated that the sum of the inner and outer magnet currents is only an indicator of the magnetic field strength.

Lastly, the effect of cathode flow rate on high voltage SPT operation was briefly investigated. This was accomplished by varying the cathode flow rate from 0.2 to $1.2 \mathrm{mg} / \mathrm{s}$ while the engine was operated at a constant anode flow rate of $3.1 \mathrm{mg} / \mathrm{s}$ and a discharge voltage of $800 \mathrm{~V}$. Magnet currents were held constant. The variation in thrust, discharge efficiency, and thruster efficiency versus cathode flow rate are plotted in figure 9 . These data show that the cathode flow had a direct effect on thrust. This was thought to be the result of neutral gas from the cathode being ingested into the channel where it is subsequently ionized and accelerated. For cathode flow rates of $0.5 \mathrm{mg} / \mathrm{s}$ and above the discharge efficiency remained essentially constant as did the cathode to ground voltage. The lack of change in discharge efficiency with changes in thrust was due to equivalent changes in discharge current which were consistent with the ingestion theory. For cathode flow rates below $0.5 \mathrm{mg} / \mathrm{s}$ the discharge efficiency dropped as the cathode-to-ground voltage became more negative. The drop in discharge efficiency could be attributable to a reduction in acceleration voltage since the applied discharge voltage was constant and the cathode-to-ground voltage became more negative. This assumes the plasma beam exiting the thruster is close to facility ground. At these lower cathode flow rates the overall thruster efficiency reached a maximum of 46 percent. Additional tests were not conducted to determine the optimal cathode flow rate at other operating conditions. The cathode flow rate for all the previously reported data was $0.4 \mathrm{mg} / \mathrm{s}$. 


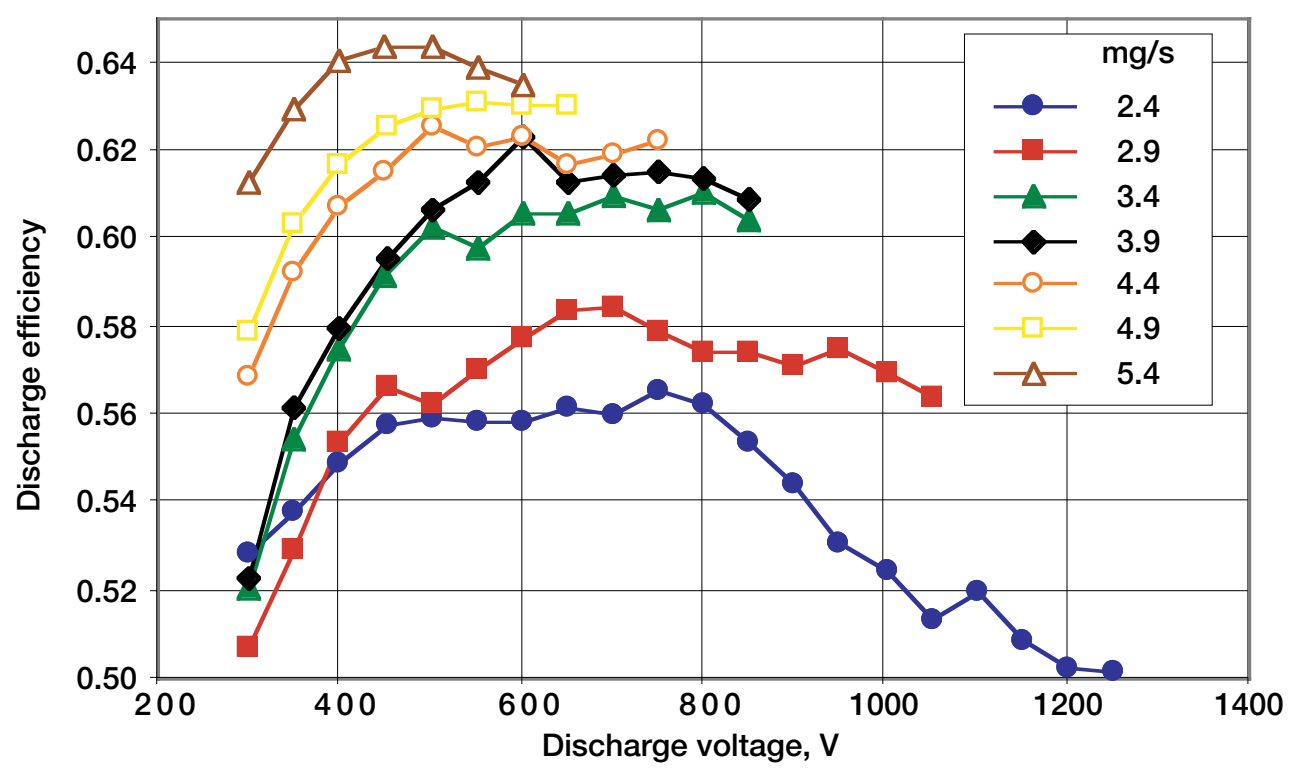

Figure 7.-Discharge efficiency versus discharge voltage.

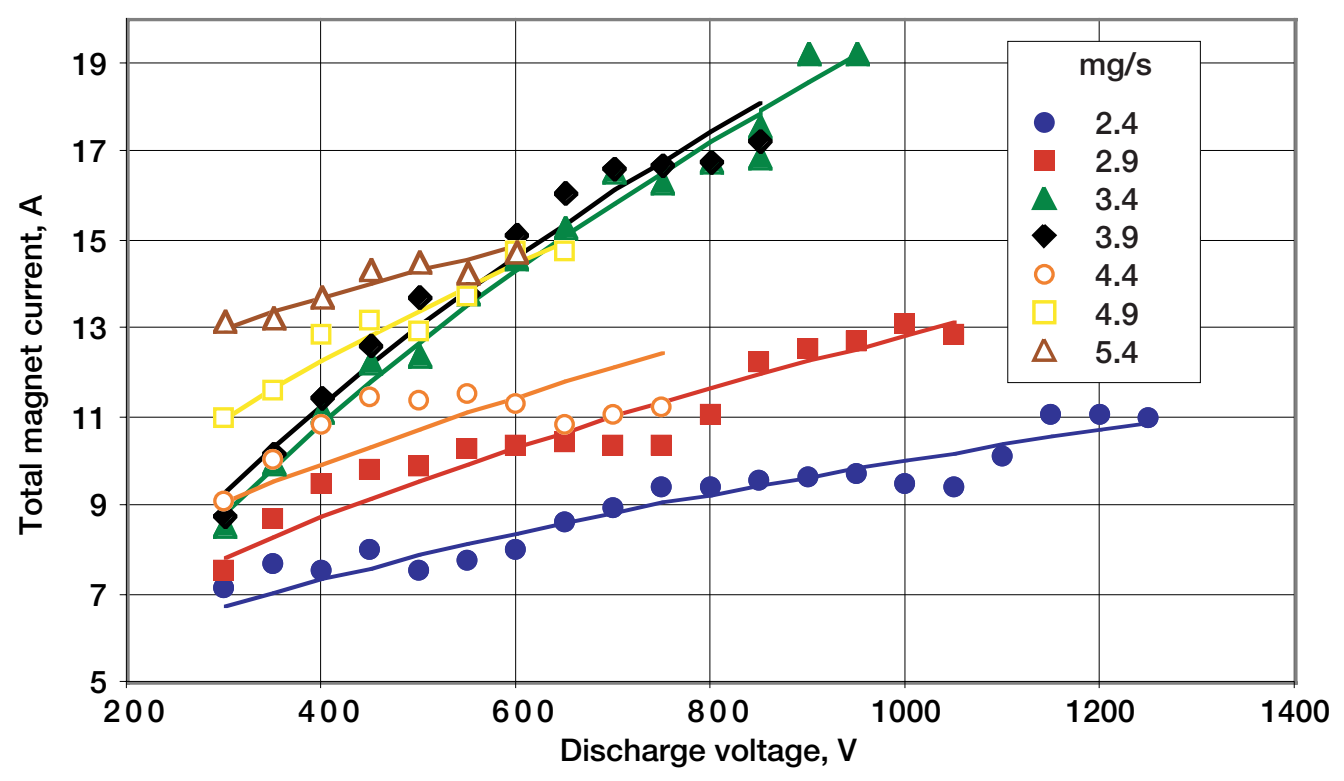

Figure 8.-Total magnet current versus discharge voltage. 


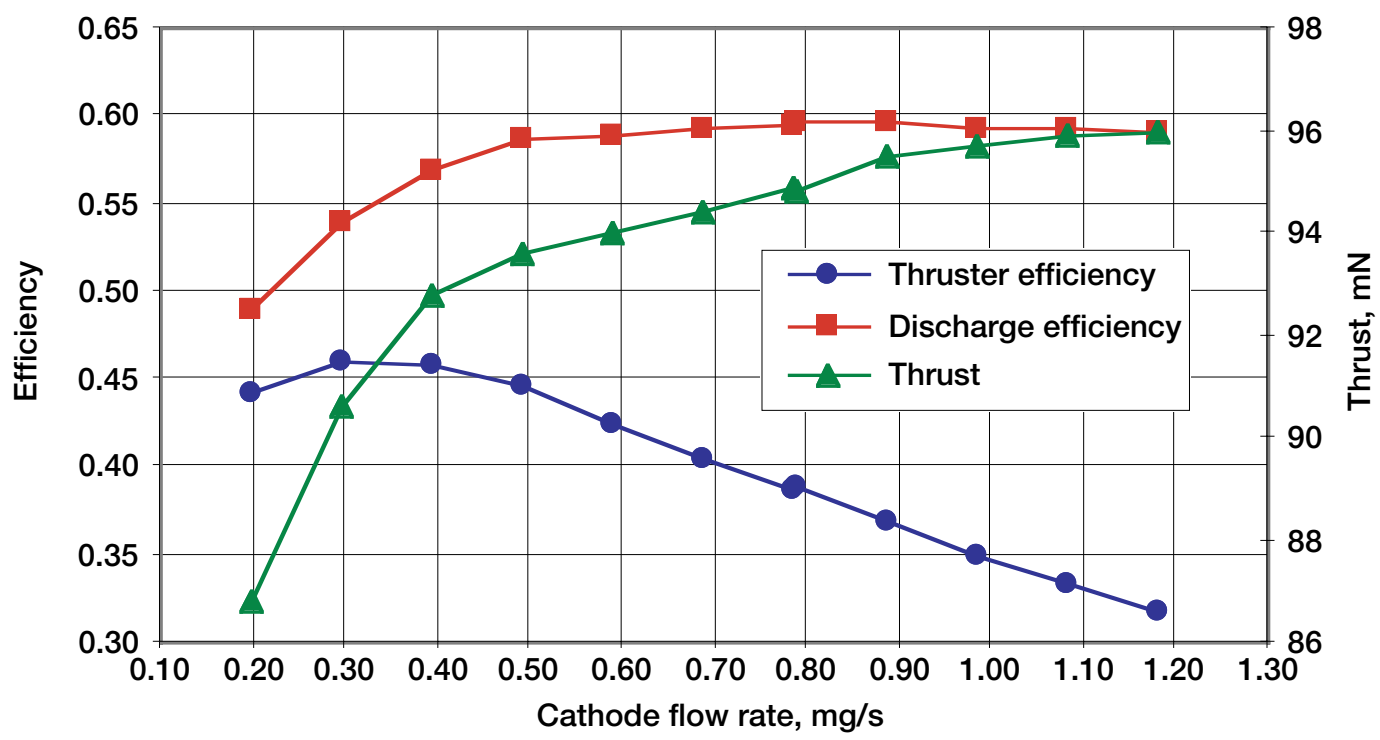

Figure 9.-Discharge efficiency, thruster efficiency, and thrust versus cathode flow rate.

\section{CONCLUSIONS}

Operation of the SPT-1 high voltage stationary plasma thruster demonstrated that it is possible to expand the operational envelope of Hall thrusters from the $300 \mathrm{~V}, 1500 \mathrm{sec}$ specific impulse range to voltages in excess of $1000 \mathrm{~V}$ and specific impulses approaching that of state-of-the-art gridded ion thrusters. Discharge specific impulses in excess of $3500 \mathrm{sec}$ were measured at discharge voltages above $1200 \mathrm{~V}$. For a given anode mass flow rate that did not result in thermal limitations the thruster could roughly be throttled over a 2:1 range in both thrust and therefore specific impulse. These data also demonstrated that discharge specific impulse is primarily dependant on discharge voltage, with a secondary anode mass flow rate effect due to more efficient operation at increased anode mass flow rates.

The performance data taken during this investigation indicated that discharge voltage can be optimized for maximum discharge efficiency. Generally this optimal discharge voltage was in the 500 to $700 \mathrm{~V}$ range although the optimal value varied with anode flow rate. These data in conjunction with measured voltage current characteristics suggest that there is a loss mechanism at high voltages that results in a higher than anticipated discharge current for a given anode flow rate. A possible cause of this is increased electron transport across the magnetic field region. Additional tests would be needed to verify this theory. The variation in optimum magnetic field strength with discharge voltage was shown to follow a $\mathrm{V}^{0.5}$ dependence as expected. Finally the effect of cathode flow fraction on thruster efficiency was investigated while operating with an $800 \mathrm{~V}$ discharge voltage. These data show there is an optimal cathode flow rate with respect to thruster efficiency that does not necessarily correspond with maximum thrust or discharge efficiency. 


\section{APPENDIX}

\begin{tabular}{|c|c|c|c|c|c|c|c|c|c|c|c|c|c|c|c|c|}
\hline $\begin{array}{c}\text { Discharge } \\
\text { voltage, } \\
\text { V }\end{array}$ & $\begin{array}{c}\text { Discharge } \\
\text { current, } \\
\text { A }\end{array}$ & $\begin{array}{c}\text { Discharge } \\
\text { power, } \\
\text { W }\end{array}$ & $\begin{array}{l}\text { Anode } \\
\text { flow, } \\
\mathrm{mg} / \mathrm{s}\end{array}$ & $\begin{array}{c}\text { Cathode } \\
\text { flow, } \\
\mathrm{mg} / \mathrm{s}\end{array}$ & $\begin{array}{c}\mathrm{V} \text { mag } \\
\text { inner, } \\
\mathrm{V}\end{array}$ & $\begin{array}{c}\text { I mag } \\
\text { inner, } \\
\mathrm{A}\end{array}$ & $\begin{array}{c}\text { V mag } \\
\text { outer, } \\
\mathrm{V}\end{array}$ & $\begin{array}{c}\text { I mag } \\
\text { outer, } \\
\text { A }\end{array}$ & $\begin{array}{c}\text { Magnet } \\
\text { power, } \\
\text { W }\end{array}$ & $\begin{array}{c}\text { Total } \\
\text { power, } \\
\text { W }\end{array}$ & $\begin{array}{c}\text { Thrust, } \\
\mathrm{mN}\end{array}$ & $\begin{array}{l}\text { Isp, } \\
\text { sec }\end{array}$ & Isp* & Eff & Eff* & $\begin{array}{c}\text { Cathode } \\
\text { ground, } \\
\text { V }\end{array}$ \\
\hline 300 & 2.07 & 621 & 2.42 & 0.43 & 2.59 & 4.06 & 3.25 & 3.05 & 20.4 & 642 & 39.9 & 1424 & 1679 & 0.39 & 0.53 & -14.8 \\
\hline 350 & 2.10 & 736 & 2.42 & 0.43 & 2.68 & 4.21 & 3.35 & 3.44 & 22.8 & 758 & 43.8 & 1563 & 1843 & 0.40 & 0.54 & -14.4 \\
\hline 401 & 2.11 & 845 & 2.42 & 0.43 & 2.7 & 4.34 & 3.37 & 3.17 & 22.4 & 868 & 47.4 & 1692 & 1994 & 0.41 & 0.55 & -14.3 \\
\hline 451 & 2.12 & 955 & 2.42 & 0.43 & 2.83 & 4.58 & 3.54 & 3.44 & 25.1 & 980 & 50.8 & 1813 & 2138 & 0.42 & 0.56 & -14.3 \\
\hline 500 & 2.12 & 1061 & 2.42 & 0.43 & 2.58 & 4.18 & 3.21 & 3.35 & 21.5 & 1082 & 53.6 & 1913 & 2255 & 0.42 & 0.56 & -13.8 \\
\hline 550 & 2.12 & 1167 & 2.42 & 0.43 & 2.6 & 4.21 & 3.22 & 3.55 & 22.4 & 1189 & 56.2 & 2006 & 2365 & 0.42 & 0.56 & -13.6 \\
\hline 600 & 2.12 & 1273 & 2.42 & 0.43 & 2.64 & 4.3 & 3.27 & 3.67 & 23.4 & 1296 & 58.7 & 2095 & 2470 & 0.42 & 0.56 & -13.6 \\
\hline 650 & 2.13 & 1385 & 2.42 & 0.43 & 2.75 & 4.5 & 3.4 & 4.12 & 26.4 & 1411 & 61.4 & 2191 & 2584 & 0.42 & 0.56 & -13.7 \\
\hline 701 & 2.14 & 1500 & 2.42 & 0.43 & 2.84 & 4.65 & 3.51 & 4.28 & 28.2 & 1528 & 63.8 & 2277 & 2685 & 0.42 & 0.56 & -14.3 \\
\hline 750 & 2.15 & 1613 & 2.42 & 0.43 & 2.94 & 4.79 & 3.62 & 4.59 & 30.7 & 1644 & 66.5 & 2373 & 2798 & 0.42 & 0.57 & -14.5 \\
\hline 800 & 2.19 & 1752 & 2.42 & 0.43 & 2.94 & 4.79 & 3.63 & 4.59 & 30.7 & 1783 & 69.1 & 2466 & 2908 & 0.42 & 0.56 & -14.3 \\
\hline 850 & 2.24 & 1905 & 2.42 & 0.43 & 3.06 & 5.01 & 3.8 & 4.51 & 32.5 & 1937 & 71.5 & 2552 & 3009 & 0.42 & 0.55 & -14.2 \\
\hline 900 & 2.30 & 2071 & 2.42 & 0.43 & 3.17 & 5.2 & 3.95 & 4.41 & 33.9 & 2105 & 73.9 & 2637 & 3110 & 0.41 & 0.54 & -14.2 \\
\hline 951 & 2.35 & 2234 & 2.42 & 0.43 & 3.2 & 5.21 & 4.01 & 4.47 & 34.6 & 2269 & 75.8 & 2705 & 3189 & 0.40 & 0.53 & -14.5 \\
\hline 1001 & 2.38 & 2382 & 2.42 & 0.43 & 3.28 & 5.36 & 4.13 & 4.12 & 34.6 & 2416 & 77.8 & 2777 & 3274 & 0.39 & 0.52 & -14.3 \\
\hline 1051 & 2.43 & 2553 & 2.42 & 0.43 & 3.25 & 5.29 & 4.12 & 4.09 & 34.0 & 2587 & 79.7 & 2844 & 3354 & 0.39 & 0.51 & -14.5 \\
\hline 1100 & 2.42 & 2663 & 2.42 & 0.43 & 3.61 & 5.83 & 4.61 & 4.29 & 40.8 & 2704 & 81.9 & 2923 & 3446 & 0.39 & 0.52 & -14.3 \\
\hline 1151 & 2.48 & 2854 & 2.42 & 0.43 & 3.98 & 6.34 & 5.1 & 4.67 & 49.1 & 2903 & 83.9 & 2994 & 3530 & 0.38 & 0.51 & -14.4 \\
\hline 1200 & 2.50 & 3001 & 2.42 & 0.43 & 4.02 & 6.34 & 5.18 & 4.67 & 49.7 & 3051 & 85.5 & 3051 & 3598 & 0.38 & 0.50 & -14.7 \\
\hline 1251 & 2.49 & 3114 & 2.42 & 0.43 & 4.06 & 6.33 & 5.25 & 4.67 & 50.2 & 3164 & 87 & 3105 & 3661 & 0.38 & 0.50 & -14.8 \\
\hline 300 & 2.37 & 713 & 2.92 & 0.43 & 2.804 & 4.098 & 3.566 & 3.39 & 23.6 & 736 & 45.92 & 1398 & 1605 & 0.39 & 0.51 & -17.7 \\
\hline 350 & 2.40 & 841 & 2.92 & 0.43 & 3.13 & 4.647 & 3.957 & 4.019 & 30.4 & 871 & 50.96 & 1551 & 1782 & 0.41 & 0.53 & -17.9 \\
\hline 400 & 2.42 & 970 & 2.92 & 0.43 & 3.305 & 4.934 & 4.161 & 4.561 & 35.3 & 1006 & 55.98 & 1704 & 1957 & 0.43 & 0.55 & -17.9 \\
\hline 451 & 2.44 & 1099 & 2.92 & 0.43 & 3.447 & 5.226 & 4.331 & 4.551 & 37.7 & 1136 & 60.234 & 1833 & 2106 & 0.44 & 0.57 & -18.0 \\
\hline 501 & 2.46 & 1232 & 2.92 & 0.43 & 3.521 & 5.402 & 4.418 & 4.496 & 38.9 & 1271 & 63.57 & 1935 & 2223 & 0.43 & 0.56 & -17.8 \\
\hline 550 & 2.48 & 1362 & 2.92 & 0.43 & 3.641 & 5.625 & 4.564 & 4.615 & 41.5 & 1404 & 67.29 & 2048 & 2353 & 0.44 & 0.57 & -17.7 \\
\hline 600 & 2.48 & 1490 & 2.92 & 0.43 & 3.734 & 5.825 & 4.68 & 4.529 & 42.9 & 1533 & 70.84 & 2156 & 2477 & 0.45 & 0.58 & -17.7 \\
\hline 650 & 2.49 & 1619 & 2.92 & 0.43 & 3.82 & 6.024 & 4.785 & 4.377 & 44.0 & 1663 & 74.24 & 2259 & 2596 & 0.45 & 0.58 & -17.8 \\
\hline 700 & 2.51 & 1755 & 2.92 & 0.43 & 3.754 & 5.914 & 4.699 & 4.443 & 43.1 & 1798 & 77.37 & 2355 & 2705 & 0.45 & 0.58 & -17.6 \\
\hline 751 & 2.59 & 1945 & 2.92 & 0.43 & 3.698 & 5.826 & 4.625 & 4.487 & 42.3 & 1987 & 81.01 & 2466 & 2832 & 0.45 & 0.58 & -16.8 \\
\hline 801 & 2.65 & 2124 & 2.92 & 0.43 & 4.156 & 6.606 & 5.214 & 4.466 & 50.7 & 2175 & 84.35 & 2567 & 2949 & 0.45 & 0.57 & -16.7 \\
\hline 851 & 2.68 & 2282 & 2.92 & 0.43 & 4.803 & 7.634 & 6.046 & 4.606 & 64.5 & 2347 & 87.408 & 2660 & 3056 & 0.44 & 0.57 & -16.7 \\
\hline 900 & 2.72 & 2446 & 2.92 & 0.43 & 4.982 & 7.842 & 6.282 & 4.681 & 68.5 & 2514 & 90.224 & 2746 & 3154 & 0.44 & 0.57 & -16.7 \\
\hline 951 & 2.75 & 2612 & 2.92 & 0.43 & 5.15 & 8.056 & 6.508 & 4.629 & 71.6 & 2684 & 93.58 & 2848 & 3272 & 0.45 & 0.57 & -16.4 \\
\hline 1001 & 2.76 & 2764 & 2.92 & 0.43 & 5.388 & 8.329 & 6.824 & 4.781 & 77.5 & 2842 & 95.78 & 2915 & 3349 & 0.44 & 0.57 & -16.3 \\
\hline 1050 & 2.78 & 2922 & 2.92 & 0.43 & 5.46 & 8.362 & 6.939 & 4.525 & 77.1 & 2999 & 98.03 & 2984 & 3427 & 0.44 & 0.56 & -16.2 \\
\hline 301 & 2.87 & 861 & 3.41 & 0.43 & 2.265 & 4.011 & 2.832 & 4.511 & 21.9 & 883 & 55.27 & 1466 & 1653 & 0.42 & 0.52 & -17.3 \\
\hline 350 & 2.89 & 1011 & 3.41 & 0.43 & 2.971 & 5.233 & 2.914 & 4.68 & 29.2 & 1041 & 61.81 & 1640 & 1848 & 0.44 & 0.55 & -17.5 \\
\hline 400 & 2.91 & 1164 & 3.41 & 0.43 & 3.498 & 6.131 & 3.108 & 4.994 & 37.0 & 1201 & 67.56 & 1792 & 2020 & 0.46 & 0.58 & -17.5 \\
\hline 450 & 2.92 & 1314 & 3.41 & 0.43 & 3.992 & 6.937 & 3.313 & 5.307 & 45.3 & 1359 & 72.81 & 1932 & 2177 & 0.47 & 0.59 & -17.6 \\
\hline 500 & 2.93 & 1466 & 3.41 & 0.43 & 4.164 & 7.166 & 3.281 & 5.23 & 47.0 & 1513 & 77.612 & 2059 & 2321 & 0.48 & 0.60 & -17.4 \\
\hline 551 & 2.96 & 1631 & 3.41 & 0.43 & 4.928 & 8.314 & 3.442 & 5.468 & 59.8 & 1690 & 81.52 & 2163 & 2438 & 0.47 & 0.60 & -17.1 \\
\hline 600 & 2.97 & 1782 & 3.41 & 0.43 & 5.367 & 8.892 & 3.584 & 5.65 & 68.0 & 1850 & 85.784 & 2276 & 2565 & 0.48 & 0.61 & -17.0 \\
\hline 651 & 2.98 & 1941 & 3.41 & 0.43 & 5.784 & 9.399 & 3.797 & 5.922 & 76.8 & 2018 & 89.56 & 2376 & 2678 & 0.48 & 0.61 & -17.0 \\
\hline 700 & 3.01 & 2108 & 3.41 & 0.43 & 6.777 & 10.6 & 3.851 & 5.962 & 94.8 & 2203 & 93.61 & 2483 & 2799 & 0.48 & 0.61 & -16.9 \\
\hline 750 & 3.05 & 2291 & 3.41 & 0.43 & 6.797 & 10.35 & 3.891 & 5.918 & 93.4 & 2384 & 97.36 & 2583 & 2912 & 0.48 & 0.61 & -16.6 \\
\hline 800 & 3.09 & 2476 & 3.41 & 0.43 & 7.338 & 10.87 & 3.939 & 5.917 & 103.1 & 2579 & 101.51 & 2693 & 3036 & 0.48 & 0.61 & -16.3 \\
\hline
\end{tabular}




\begin{tabular}{|c|c|c|c|c|c|c|c|c|c|c|c|c|c|c|c|c|}
\hline $\begin{array}{c}\text { Discharge } \\
\text { voltage, } \\
\text { V }\end{array}$ & $\begin{array}{c}\text { Discharge } \\
\text { current, } \\
\text { A }\end{array}$ & $\begin{array}{l}\text { Discharge } \\
\text { power, } \\
\text { W }\end{array}$ & $\begin{array}{l}\text { Anode } \\
\text { flow, } \\
\mathrm{mg} / \mathrm{s}\end{array}$ & $\begin{array}{c}\text { Cathode } \\
\text { flow, } \\
\mathrm{mg} / \mathrm{s}\end{array}$ & $\begin{array}{c}\mathrm{V} \text { mag } \\
\text { inner, } \\
\mathrm{V}\end{array}$ & $\begin{array}{c}\text { I mag } \\
\text { inner, } \\
\mathrm{A}\end{array}$ & $\begin{array}{c}\mathrm{V} \text { mag } \\
\text { outer, } \\
\mathrm{V}\end{array}$ & $\begin{array}{c}\text { I mag } \\
\text { outer, } \\
\text { A }\end{array}$ & $\begin{array}{c}\text { Magnet } \\
\text { power, } \\
\text { W }\end{array}$ & $\begin{array}{c}\text { Total } \\
\text { power, } \\
\text { W }\end{array}$ & $\begin{array}{c}\text { Thrust, } \\
\mathrm{mN}\end{array}$ & $\begin{array}{l}\text { Isp, } \\
\text { sec }\end{array}$ & Isp* & Eff & Eff* & $\begin{array}{c}\text { Cathode } \\
\text { ground, } \\
\text { V }\end{array}$ \\
\hline 850 & 3.13 & 2659 & 3.41 & 0.43 & 7.843 & 11.37 & 3.668 & 5.473 & 109.2 & 2768 & 104.63 & 2776 & 3129 & 0.48 & 0.60 & -15.8 \\
\hline 851 & 3.13 & 2660 & 3.41 & 0.43 & 7.334 & 11.54 & 9.277 & 6.056 & 140.8 & 2801 & 102.15 & 2710 & 3055 & 0.45 & 0.58 & -19.1 \\
\hline 900 & 3.17 & 2852 & 3.41 & 0.43 & 8.641 & 12.88 & 11.036 & 6.326 & 181.1 & 3033 & 104.98 & 2785 & 3140 & 0.44 & 0.57 & -19.5 \\
\hline 951 & 3.22 & 3061 & 3.41 & 0.43 & 9.044 & 13.03 & 11.621 & 6.207 & 189.9 & 3251 & 108.54 & 2880 & 3246 & 0.44 & 0.56 & -19.4 \\
\hline 300 & 3.33 & 1000 & 3.90 & 0.43 & 2.4 & 4.3 & 2.87 & 4.49 & 23.2 & 1023 & 63.87 & 1502 & 1669 & 0.43 & 0.52 & -16.9 \\
\hline 351 & 3.34 & 1171 & 3.90 & 0.43 & 3.26 & 5.77 & 2.8 & 4.42 & 31.2 & 1202 & 71.61 & 1684 & 1871 & 0.46 & 0.56 & -16.9 \\
\hline 401 & 3.36 & 1346 & 3.90 & 0.43 & 3.71 & 6.53 & 3.11 & 4.89 & 39.4 & 1385 & 78.02 & 1834 & 2038 & 0.47 & 0.58 & -17.1 \\
\hline 451 & 3.37 & 1519 & 3.90 & 0.43 & 4.24 & 7.37 & 3.35 & 5.26 & 48.9 & 1568 & 84.04 & 1976 & 2196 & 0.49 & 0.60 & -17.1 \\
\hline 501 & 3.38 & 1692 & 3.90 & 0.43 & 4.763 & 8.141 & 3.609 & 5.606 & 59.0 & 1751 & 89.47 & 2104 & 2338 & 0.49 & 0.61 & -17.2 \\
\hline 551 & 3.40 & 1870 & 3.90 & 0.43 & 4.816 & 8.137 & 3.668 & 5.65 & 59.9 & 1929 & 94.56 & 2223 & 2471 & 0.50 & 0.61 & -17.2 \\
\hline 600 & 3.41 & 2046 & 3.90 & 0.43 & 5.801 & 9.532 & 3.643 & 5.606 & 75.7 & 2122 & 99.76 & 2346 & 2606 & 0.51 & 0.62 & -16.9 \\
\hline 650 & 3.46 & 2251 & 3.90 & 0.43 & 6.42 & 10.3 & 3.791 & 5.79 & 88.1 & 2339 & 103.76 & 2440 & 2711 & 0.50 & 0.61 & -16.6 \\
\hline 700 & 3.51 & 2461 & 3.90 & 0.43 & 6.756 & 10.58 & 4.024 & 6.074 & 95.9 & 2557 & 108.6 & 2554 & 2837 & 0.50 & 0.61 & -16.6 \\
\hline 750 & 3.56 & 2673 & 3.90 & 0.43 & 6.976 & 10.68 & 4.005 & 5.985 & 98.5 & 2772 & 113.27 & 2663 & 2959 & 0.50 & 0.61 & -17.3 \\
\hline 801 & 3.61 & 2890 & 3.90 & 0.43 & 7.296 & 10.94 & 3.935 & 5.843 & 102.8 & 2993 & 117.69 & 2767 & 3075 & 0.50 & 0.61 & -15.9 \\
\hline 850 & 3.65 & 3102 & 3.90 & 0.43 & 8.022 & 11.69 & 3.75 & 5.561 & 114.6 & 3217 & 121.43 & 2855 & 3173 & 0.49 & 0.61 & -15.46 \\
\hline 301 & 3.85 & 1158 & 4.39 & 0.43 & 2.57 & 4.57 & 3.1 & 4.5 & 25.7 & 1184 & 76.1 & 1607 & 1765 & 0.48 & 0.57 & -15.5 \\
\hline 350 & 3.87 & 1356 & 4.39 & 0.43 & 2.91 & 5.16 & 3.52 & 4.9 & 32.3 & 1388 & 84 & 1773 & 1948 & 0.50 & 0.59 & -16.2 \\
\hline 401 & 3.90 & 1562 & 4.39 & 0.43 & 3.15 & 5.55 & 3.83 & 5.27 & 37.7 & 1600 & 91.3 & 1928 & 2118 & 0.51 & 0.61 & -16.3 \\
\hline 450 & 3.92 & 1765 & 4.39 & 0.43 & 3.35 & 5.82 & 4.09 & 5.64 & 42.6 & 1807 & 97.7 & 2063 & 2266 & 0.51 & 0.62 & -16.2 \\
\hline 500 & 3.94 & 1972 & 4.39 & 0.43 & 3.33 & 5.71 & 4.08 & 5.62 & 41.9 & 2014 & 104.1 & 2198 & 2415 & 0.52 & 0.63 & -15.9 \\
\hline 550 & 3.98 & 2190 & 4.39 & 0.43 & 3.32 & 5.63 & 4.08 & 5.86 & 42.6 & 2233 & 109.3 & 2308 & 2535 & 0.52 & 0.62 & -14.7 \\
\hline 601 & 4.03 & 2422 & 4.39 & 0.43 & 3.43 & 5.85 & 4.24 & 5.41 & 43.0 & 2465 & 115.2 & 2432 & 2672 & 0.52 & 0.62 & -14.2 \\
\hline 650 & 4.11 & 2672 & 4.39 & 0.43 & 3.24 & 5.43 & 4.01 & 5.41 & 39.3 & 2712 & 120.4 & 2542 & 2793 & 0.52 & 0.62 & -13.8 \\
\hline 700 & 4.16 & 2912 & 4.39 & 0.43 & 3.28 & 5.45 & 4.07 & 5.58 & 40.6 & 2953 & 125.9 & 2658 & 2920 & 0.52 & 0.62 & -14.3 \\
\hline 750 & 4.20 & 3151 & 4.39 & 0.43 & 3.36 & 5.55 & 4.18 & 5.67 & 42.3 & 3194 & 131.3 & 2772 & 3046 & 0.53 & 0.62 & -14.4 \\
\hline 300 & 4.38 & 1316 & 4.89 & 0.43 & 3.06 & 4.85 & 3.79 & 6.1 & 38.0 & 1354 & 86.3 & 1653 & 1800 & 0.49 & 0.58 & -15.7 \\
\hline 350 & 4.39 & 1537 & 4.89 & 0.43 & 3.32 & 5.27 & 4.1 & 6.34 & 43.5 & 1581 & 95.2 & 1824 & 1986 & 0.51 & 0.60 & -15.9 \\
\hline 400 & 4.41 & 1766 & 4.89 & 0.43 & 3.62 & 5.68 & 4.47 & 7.21 & 52.8 & 1819 & 103.2 & 1977 & 2152 & 0.52 & 0.62 & -16.0 \\
\hline 451 & 4.42 & 1992 & 4.89 & 0.43 & 3.79 & 5.95 & 4.69 & 7.23 & 56.5 & 2049 & 110.4 & 2115 & 2303 & 0.53 & 0.63 & -15.9 \\
\hline 500 & 4.46 & 2232 & 4.89 & 0.43 & 3.71 & 5.81 & 4.6 & 7.09 & 54.2 & 2286 & 117.2 & 2245 & 2444 & 0.53 & 0.63 & -15.5 \\
\hline 551 & 4.51 & 2483 & 4.89 & 0.43 & 3.92 & 6.06 & 4.86 & 7.63 & 60.8 & 2544 & 123.8 & 2372 & 2582 & 0.54 & 0.63 & -14.5 \\
\hline 601 & 4.57 & 2744 & 4.89 & 0.43 & 4.44 & 6.89 & 5.53 & 7.82 & 73.8 & 2818 & 130 & 2490 & 2711 & 0.53 & 0.63 & -14.7 \\
\hline 651 & 4.64 & 3018 & 4.89 & 0.43 & 4.44 & 6.77 & 5.53 & 7.97 & 74.1 & 3092 & 136.4 & 2613 & 2845 & 0.54 & 0.63 & -14.3 \\
\hline 300 & 4.89 & 1468 & 5.38 & 0.43 & 3.52 & 5.07 & 4.35 & 8.1 & 53.1 & 1522 & 98.4 & 1725 & 1864 & 0.52 & 0.61 & -11.9 \\
\hline 350 & 4.89 & 1713 & 5.38 & 0.43 & 3.79 & 5.61 & 4.69 & 7.64 & 57.1 & 1770 & 107.7 & 1888 & 2040 & 0.54 & 0.63 & -12.3 \\
\hline 400 & 4.90 & 1960 & 5.38 & 0.43 & 4 & 5.97 & 4.97 & 7.73 & 62.3 & 2022 & 116.2 & 2037 & 2201 & 0.55 & 0.64 & -12.5 \\
\hline 450 & 4.91 & 2210 & 5.38 & 0.43 & 4.16 & 6.16 & 5.16 & 8.15 & 67.7 & 2278 & 123.7 & 2169 & 2344 & 0.55 & 0.64 & -12.4 \\
\hline 500 & 4.94 & 2471 & 5.38 & 0.43 & 4.22 & 6.24 & 5.24 & 8.26 & 69.6 & 2541 & 130.8 & 2293 & 2478 & 0.55 & 0.64 & -12.4 \\
\hline 550 & 5.01 & 2757 & 5.38 & 0.43 & 4.17 & 6.14 & 5.18 & 8.09 & 67.5 & 2825 & 137.7 & 2414 & 2609 & 0.55 & 0.64 & -12.2 \\
\hline 600 & 5.09 & 3056 & 5.38 & 0.43 & 4.29 & 6.25 & 5.32 & 8.52 & 72.1 & 3128 & 144.5 & 2533 & 2738 & 0.55 & 0.63 & -12.0 \\
\hline
\end{tabular}




\section{REFERENCES}

1. Day, M., et. al.: "Stationary Plasma Thruster-100 Subsystem Qualification Status," AIAA-96-2713, July 1996.

2. Hargus, W., Fife, M., McFall, K., Jankovsky, R., and Mason, L.: "Status of U.S. Testing of the High Performance Hall System SPT-140 Hall Thruster," AIAA-2000-1053, January 2000.

3. Lynn, P., Osborn, M., Sankovic, J., and Caveny, L.: "Electric Propulsion Demonstration Module (EPDM) Flight Hall Thruster System,” IEPC-97-100, August 1997.

4. Oleson, S. and Myers, R.: "Advanced Propulsion for Geostationary Orbit Insertion and North-South Station Keeping," AIAA-95-2513, July 1995.

5. Oleson, S.: "Electric Propulsion for Low Earth Orbit Communication Satellites," IEPC-97-148, August 1997.

6. Spanjers, G., Birjan, M., and Lawrence, T.: "The USAF Electric Propulsion Research Program," AIAA-2000-3146, July 2000.

7. Oleson, S.: "Advanced Propulsion for Space Solar Power Satellites," AIAA-99-2872, June 1999.

8. Gefert, L., Hack, J., and Kerslake, T.: "Options for the Human Exploration of Mars Using Solar Electric Power," Proceedings of the Space Technology and Applications International Forum-1999.

9. Oleson, S.: "Mission Advantages of Constant Power Variable Isp Electrostatic Thrusters," AIAA-2000-3413, July 2000.

10. Jacobson, D., Jankovsky, R., and Manzella, D.: "High Voltage TAL Performance," AIAA-2001-3777, July 2001.

11. Sankovic, J.M., Haag, T.W., and Manzella, D.H.: “Operating Characteristics of the Russian D-55 Thruster with Anode Layer," AIAA-94-3011, June 1994.

12. Sankovic, J.M., Haag, T.W., and Manzella, D.H.: "Performance Evaluation of a $4.5 \mathrm{~kW}$ SPT Thruster," IEPC-95-30, Sept. 1995.

13. Gavryushin, V., et. al.: "Study of the Effect of Magnetic Field Variations, Channel Geometry and its Wall Contamination Upon the SPT Performance," AIAA-94-2854, June 1994.

14. Belan, N., et. al.: Statsionarnyye Plasmennyye Dvigateli, USSR State Committee on Public Education, N. Yr. Zhukovskiy Kharkov Order of Lenin Institute, Kharkov, 1989. 


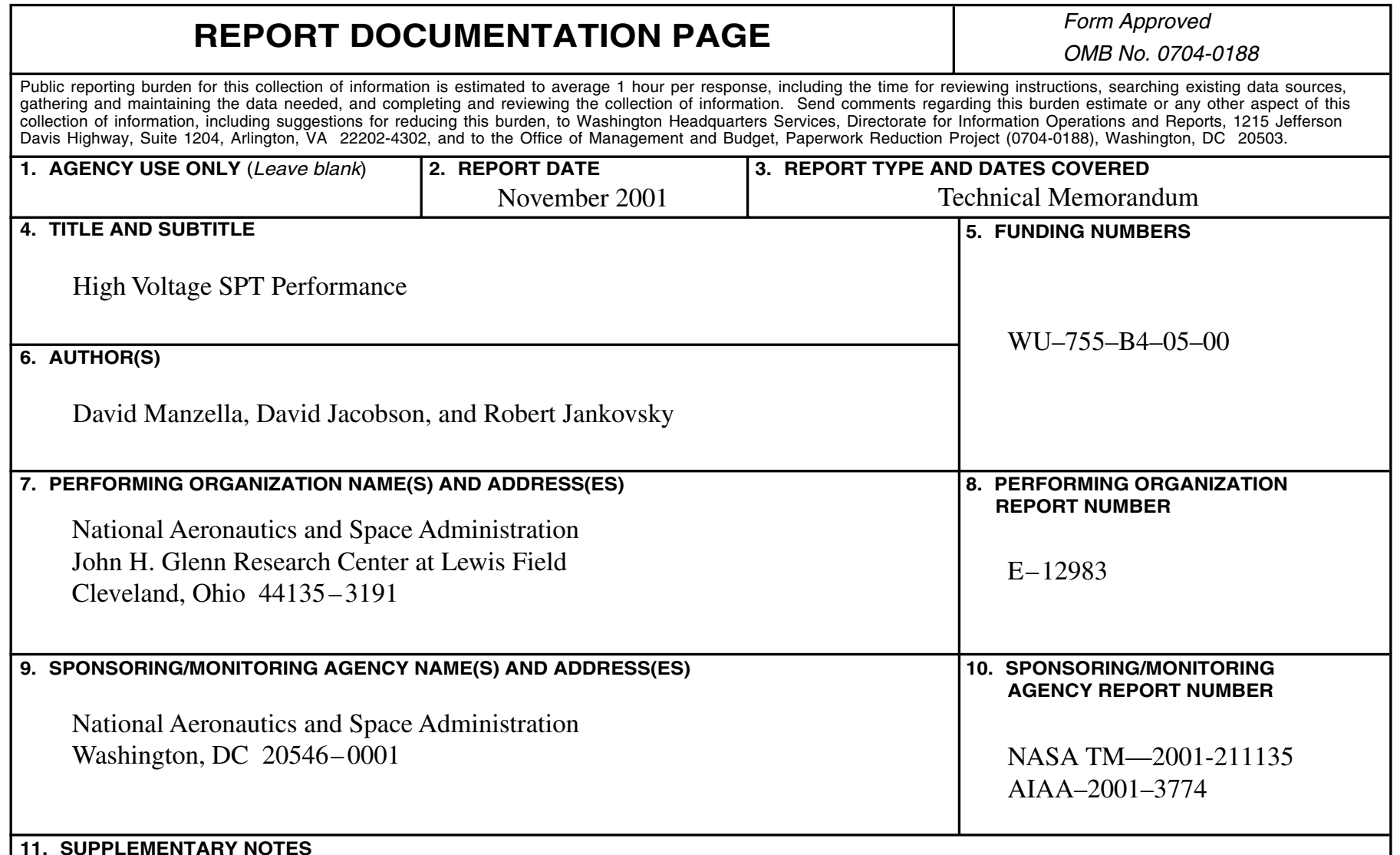

11. SUPPLEMENTARY NOTES

Prepared for the 37th Joint Propulsion Conference and Exhibit cosponsored by the AIAA, SAE, AIChE, and ASME, Salt Lake City, Utah, July 8-11, 2001. David Manzella, University of Toledo, 2801 W. Bancroft Street, Toledo, Ohio 43606-3328; David Jacobson and Robert Jankovsky, NASA Glenn Research Center. Responsible person,

David Manzella, organization code 5430, 216-977-7432.

12a. DISTRIBUTION/AVAILABILITY STATEMENT

12b. DISTRIBUTION CODE

Unclassified - Unlimited

Subject Category: 20

Distribution: Nonstandard

Available electronically at http://gltrs.grc.nasa.gov/GLTRS

This publication is available from the NASA Center for AeroSpace Information, 301-621-0390.

13. ABSTRACT (Maximum 200 words)

A $2.3 \mathrm{~kW}$ stationary plasma thruster designed to operate at high voltage was tested at discharge voltages between 300 and $1250 \mathrm{~V}$. Discharge specific impulses between 1600 and $3700 \mathrm{sec}$ were demonstrated with thrust between 40 and $145 \mathrm{mN}$. Test data indicated that discharge voltage can be optimized for maximum discharge efficiency. The optimum discharge voltage was between 500 and $700 \mathrm{~V}$ for the various anode mass flow rates considered. The effect of operating voltage on optimal magnet field strength was investigated. The effect of cathode flow rate on thruster efficiency was considered for an $800 \mathrm{~V}$ discharge.

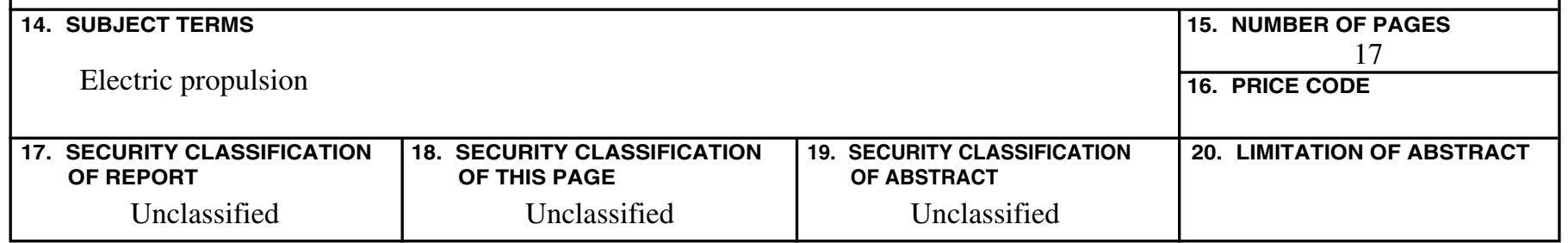

NSN 7540-01-280-5500

Standard Form 298 (Rev. 2-89) 